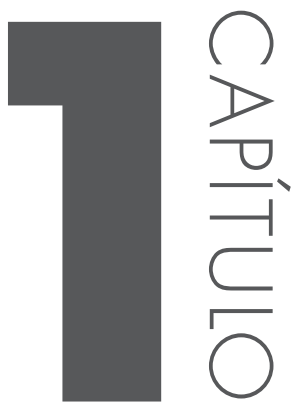

\title{
ANATOMIA DA CAVIDADE ORAL
}

Miguel Carlos Madeira

Horácio Faig Leite

Roelf J. Cruz Rizzolo

\subsection{ANATOMIA DESCRITIVA DA BOCA}

A cavidade da boca ou cavidade oral é a parte inicial do sistema digestório. Localizase no terço inferior da face e comunica-se com o exterior pela abertura oral e com a parte oral da faringe (orofaringe) através de uma abertura ampla denominada istmo da garganta (das fauces).

Quando totalmente fechada, é dividida pelos arcos dentais em duas porções: uma anterior anterolateral, menor, o vestíbulo da boca, e a outra posterior e maior, a cavidade própria da boca que apresenta uma forma ovalada. Com os 
dentes em oclusão, estas duas partes comunicam-se pelo espaço entre os últimos molares e a borda anterior do ramo da mandíbula.

A cavidade da boca tem como limites: anterior e lateralmente os lábios e bochechas, posteriormente o istmo da garganta, superiormente o palato e inferiormente o soalho da boca, onde encontramos fixada a língua.

São formações limitantes da cavidade da boca: os lábios, bochechas, palato, soalho e istmo da garganta.

\subsubsection{LÁBIOS}

Como nas demais formações limitantes, os lábios apresentam-se estratificados, com várias camadas, entre as quais se encontram vasos e nervos. São cinco as suas camadas, denominadas de fora para dentro: 1. camada cutânea, apresentando glândulas sudoríferas e sebáceas; 2 . tela subcutânea; 3. camada muscular; 4. camada submucosa com glândulas salivares e vasos sanguíneos; 5 . camada mucosa.

Quando os lábios estão em contato, delimitam a rima da boca, cujas extremidades constituem os ângulos da boca (comissura labial). Normalmente, o lábio superior apresenta menor mobilidade do que o inferior.

O lábio superior é limitado superiormente pelo nariz, ao qual se une por meio de um sulco raso e largo denominado de filtro, é separado das bochechas, de ambos os lados, por um sulco profundo e muitas vezes variável em comprimento e profundidade, chamado de sulco nasolabial.

O lábio inferior apresenta como limite externo, inferiormente, um sulco que o separa do mento denominado de sulco labiomentoniano, e outro que vai do ângulo da boca à base da mandíbula, o sulco labiomarginal. Estes dois sulcos nas pessoas de mais idade tornam-se bastante pronunciados. (Figura 1.1)

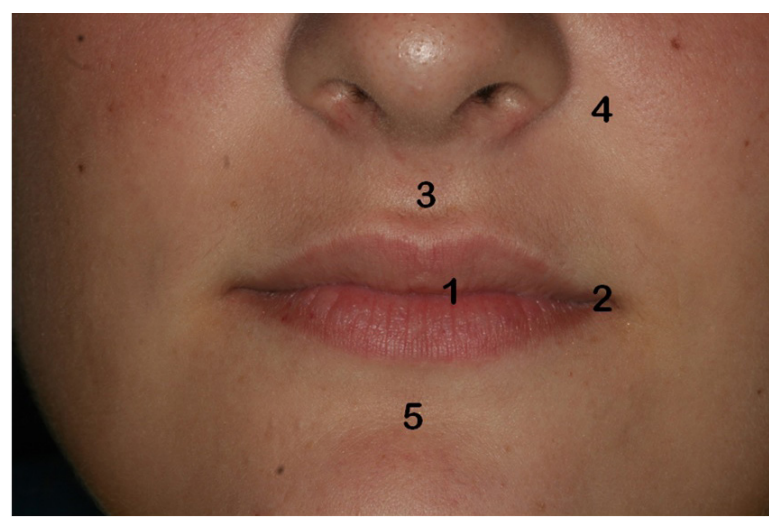

1. Rima da boca

2. Ângulo da boca

3. Filtro

4. Sulco nasolabial

5. Sulco labiomarginal

Figura 1.1 - Vista externa da boca 
A face interna dos lábios está relacionada com o vestíbulo da boca e com os arcos dentais, sendo revestida por uma mucosa de coloração rósea e aspecto liso brilhante. Esta face interna continua com a mucosa alveolar fazendo uma reflexão em forma de fundo de saco, o fórnice do vestíbulo. No vestíbulo podemos notar uma prega mucosa mediana, o frênulo (freio) do lábio; outras pregas podem aparecer como os freios laterais (Figuras 1.2 e 1.3). O frênulo do lábio superior é normalmente mais pronunciado do que o inferior e algumas vezes pode necessitar de uma redução cirúrgica (frenectomia). Na parte mucosa do lábio inferior, podemos notar pequenas elevações das glândulas salivares menores aí encontradas e que podem ser sentidas com a ponta da língua ou com a palpação digital. A camada muscular dos lábios é formada pelo músculo orbicular da boca e por algumas fibras musculares que convergem para as bordas livres dos lábios.

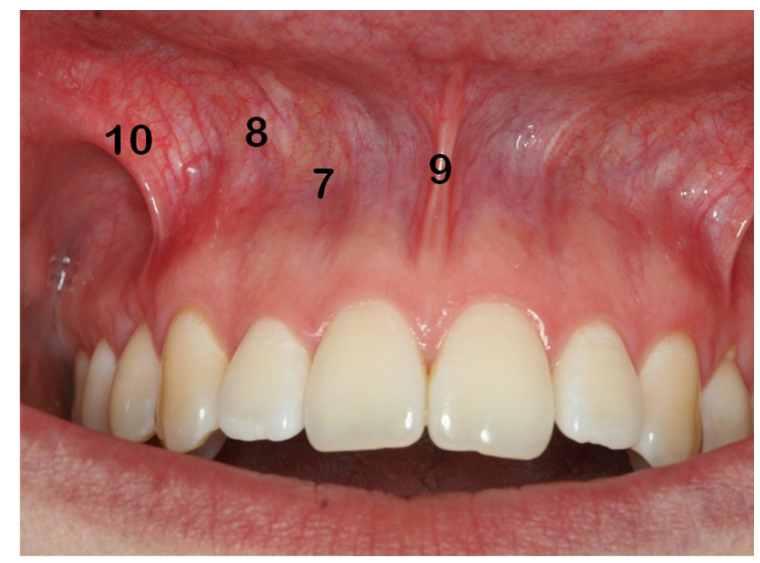

7. Mucosa alveolar

8. Fórnice do vestíbulo

9. Freio labial superior

10. Freio lateral

Figura 1.2 - Vestíbulo da boca, arco superior

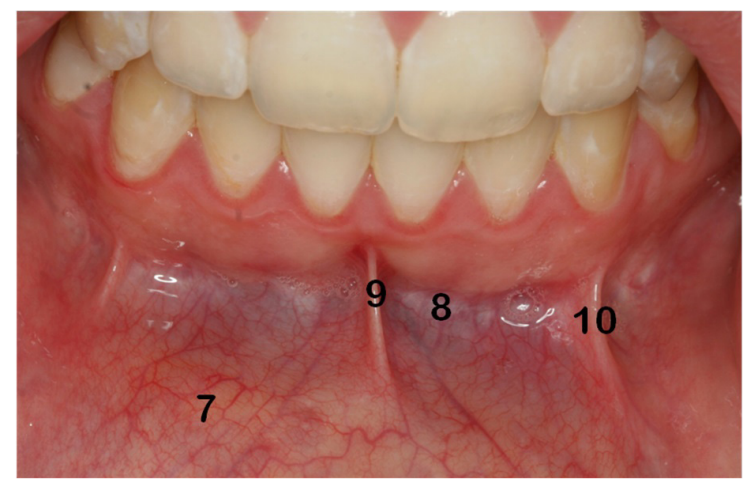

7. Mucosa labial

8. Fórnice do vestíbulo

9. Freio labial inferior

10. Freio lateral

Figura 1.3 - Vestíbulo da boca, arco inferior 


\subsubsection{BOCHECHA}

A bochecha forma a parede lateral da cavidade da boca, apresentando as mesmas camadas que encontramos nos lábios. Vários elementos anatômicos como o músculo bucinador, o corpo adiposo da bochecha, o ducto parotídeo e alguns músculos da expressão facial (mímicos) podem ser vistos na camada subcutânea. Seu limite externo é extenso e não muito preciso; internamente este limite é menor e está delimitado em sua porção superior e inferior pelo fórnice do vestíbulo e posteriormente pela prega pterigomandibular. Esta prega é formada pelo ligamento pterigomandibular recoberto por mucosa e é bastante visível quando se abre amplamente a boca (Figura 1.4).

Internamente, na altura do segundo molar superior, abre-se o ducto parotídeo que é protegido por uma saliência, normalmente de forma triangular, a papila parotídea.

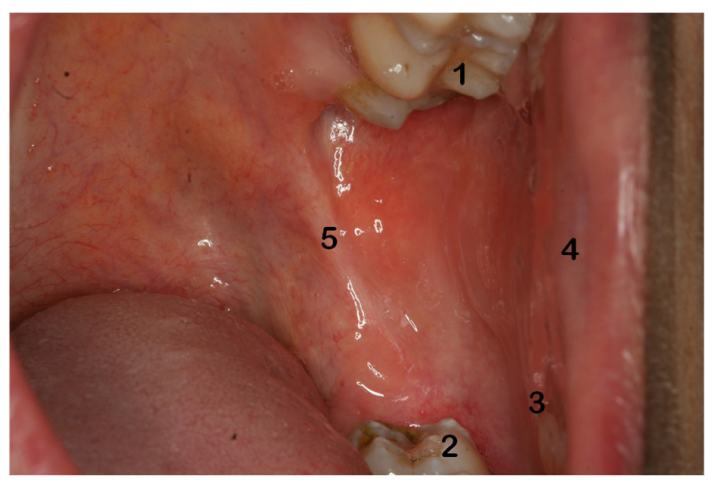

1. Dente superior

2. Dente inferior

3. Fórnice do vestíbulo

4. Bochecha

5. Prega pterigomandibular

Figura 1.4 - Face interna da bochecha

\subsubsection{VESTÍBULO}

O vestíbulo oral é delimitado externamente pelos lábios e bochechas e internamente pelos dentes e processos alveolares recobertos pela mucosa. A mucosa interna, tanto dos lábios como das bochechas, continua para cima e para baixo e forma um sulco que os une, que é o fórnice do vestíbulo. Após a mucosa, se dobrar no fórnice, esta passa a recobrir o osso alveolar e recebe o nome de mucosa alveolar.

Esta comunica-se com uma mucosa bastante especializada, espessa e mais clara chamada de gengiva. O limite entre estas duas mucosas é perceptível por meio de uma linha sinuosa, a junção mucogengival (Fígura 1.5). Nos indivíduos negros, 
a gengiva pode apresentar-se bastante pigmentada (escura) devido a alta presença de melanina (Figura 1.6). A gengiva é dividida segundo suas características em gengiva inserida e livre, pois é bem presa ao osso alveolar, mas tem a borda que circunda cada dente não aderente, formando o sulco gengival de 1 a $2 \mathrm{~mm}$ de profundidade.

No vestíbulo da boca, encontramos pregas mucosas, que unem a mucosa à gengiva dos lábios e da bochecha. São os freios labiais superior e inferior (estruturas medianas) e os freios laterais, menores, encontrados na região dos dentes caninos e pré-molares.

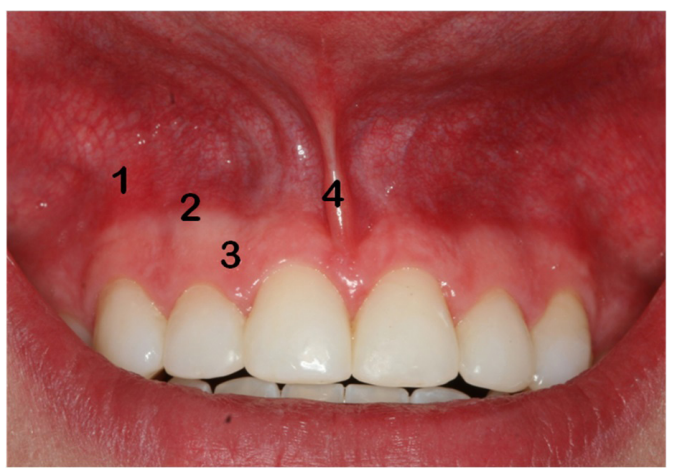

1. Mucosa alveolar

2. Gengiva

3. Junção mucogengival

4. Freio labial superior

Figura 1.5 - Vestíbulo da boca, arco superior

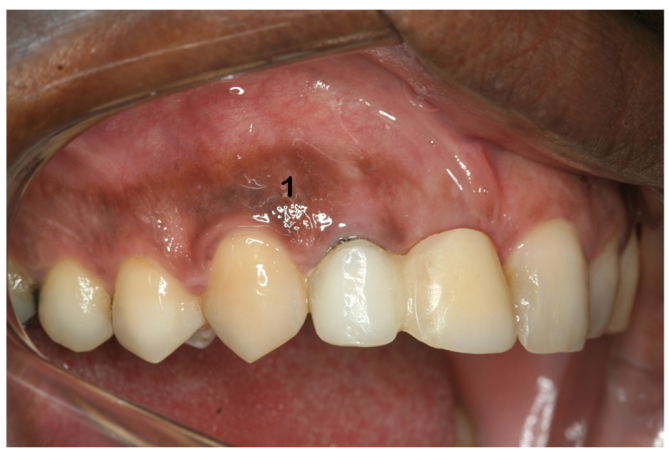

Figura 1.6 - Gengiva pigmentada por melanina (1) 


\subsubsection{PALATO}

O palato ou teto da cavidade oral é divido em uma porção anterior ou palato duro e outra posterior ou palato mole (véu palatino). A mucosa que reveste o palato duro é espessa e unida ao periósteo (mucoperiósteo).

A rafe palatina é uma saliência linear encontrada na porção mediana do palato, vestígio da união embriológica das duas maxilas. Na linha mediana e atrás dos dentes incisivos centrais superiores, encontramos a papila incisiva que recebe este nome por sua localização e por estar em cima da fossa incisiva. Partindo lateralmente da papila incisiva, encontramos as pregas palatinas transversas (rugas palatinas), que têm por função auxiliar na mastigação ao prender o alimento contra a língua. Estas pregas são características de cada indivíduo, em número e forma (Figura 1.7).

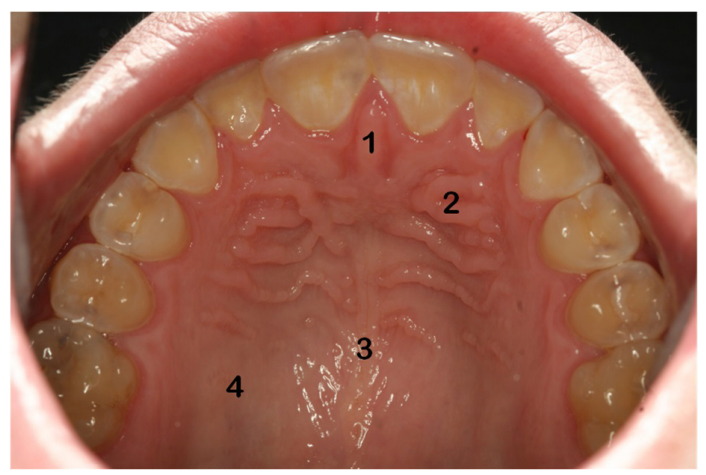

1. Papila incisiva

2. Pregas palatinas

transversas

3. Rafe palatina

4. Mucosa do palato

Figura 1.7 - Porção anterior do palato duro

Entre a mucosa e a parte posterior do palato ósseo, encontramos glândulas salivares menores (glândulas palatinas) que se estendem em direção ao palato mole, localizando-se entre a mucosa e a camada muscular.

O limite entre o palato duro e o palato mole pode ser reconhecido facilmente no indivíduo vivo, devido a diferença de coloração entre ambas as regiões.

$\mathrm{Na}$ borda livre do palato mole (véu palatino), na sua porção mediana, encontramos uma projeção cônica de comprimento variável chamada de úvula. Lateralmente, esta borda livre divide-se em duas pregas, uma de cada lado, que são os arcos palatinos do istmo da garganta (Figura 1.8). 


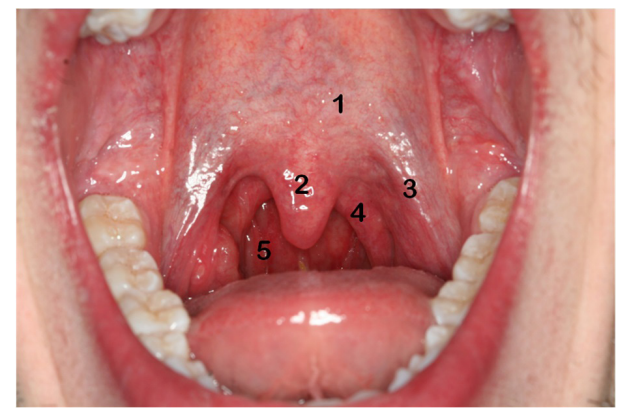

1. Palato mole

2. Úvula

3. Arco palatoglosso

4. Arco palatofaríngeo

5. Istmo da garganta

Figura 1.8 - Palato mole e istmo da garganta

O palato mole é formado, de ambos os lados, pelos músculos elevador e tensor do véu palatino, palatoglosso, palatofaríngeo e da úvula. (A descrição anatômica resumida desses músculos encontra-se na parte 2: anatomia funcional da boca)

\subsubsection{ISTMO DA GARGANTA}

O istmo da garganta é a comunicação entre a cavidade da boca com a parte oral da faringe (orofaringe). Acima está delimitado pelo palato mole, abaixo pela raiz da língua e lateralmente pelos arcos palatoglosso e palatofaríngeo. $\mathrm{O}$ arco palatoglosso é formado pelo músculo do mesmo nome, sendo mais anterior e lateral do que o arco palatofaríngeo (m. palatofaríngeo) que se evidencia mais medialmente do que o anterior. Entre os dois arcos situa-se a fossa tonsilar, onde se localiza a tonsila (amígdala) palatina. Esta tonsila é uma massa de tecido linfoide de tamanho variável e que muitas vezes acaba tendo que ser removida por meio de cirurgia (tonsilectomia).

\subsubsection{SOALHO DA BOCA}

O soalho da boca é formado exclusivamente por tecidos moles, sendo totalmente recoberto por uma mucosa delgada, vermelha, translúcida e apresentando-se frouxamente fixada aos planos profundos. A mucosa do soalho da boca continua com a mucosa da língua. Quando a ponta da língua é levantada em direção ao palato, encontramos uma prega mucosa mediana que atinge em cima a face inferior da língua, o frênulo da língua. Em alguns casos, este frênulo pode se fixar muito alto na face lingual do processo alveolar mandibular, dificultando, principalmente, a fonação e deve ser corrigido cirurgicamente. Próximo da extre- 
midade anterior de cada frênulo da língua, encontramos a carúncula sublingual, onde se abrem os ductos das glândulas submandibulares. (Figura 1.9)

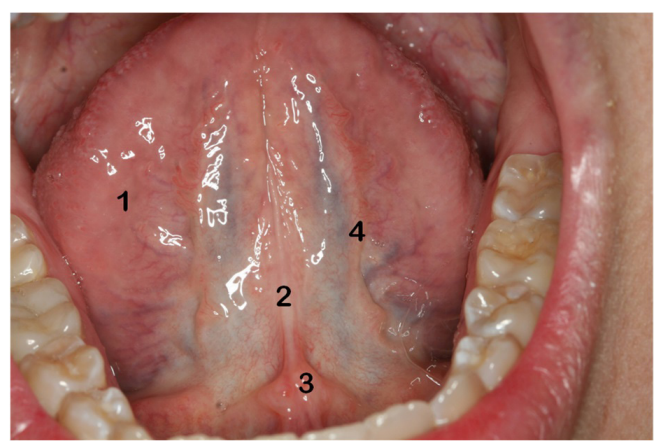

1. Face inferior da língua

2. Freio da língua

3. Carúncula sublingual

4. Prega franjada

Figura 1.9 - Soalho da boca com a língua erguida

Em direção lateroposterior, e mais ou menos paralela ao corpo da mandíbula, encontramos outra elevação denominada prega sublingual, que é formada devido ao relevo da glândula sublingual e do ducto da glândula submandibular (Figura 1.10).

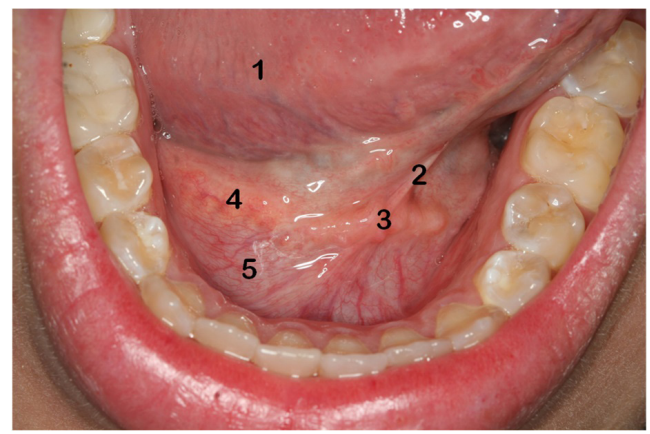

1. Margem da língua

2. Freio da língua

3. Carúncula sublingual

4. Prega sublingual

5. Mucosa do soalho bucal

Figura 1.10 - Soalho da boca com a língua lateralizada

Abaixo da mucosa do soalho da boca encontramos os músculos milo-hióideos, de ambos os lados, que formam um diafragma incompleto, permitindo a comunicação entre as regiões sublingual e supra-hióidea.

No espaço entre o músculo milo-hióideo e a mucosa, encontramos vários elementos anatômicos importantes como a glândula sublingual, ducto da glândula submandibular, músculo gênio-hióideo, nervos lingual e hipoglosso e vasos sublinguais. 


\subsubsection{LÍNGUA}

A língua é um órgão muscular, localizada na cavidade própria da boca, presa por sua base ao soalho da cavidade oral. Está constituída por músculos extrínsecos e intrínsecos. Os músculos extrínsecos a prendem à mandíbula, ao osso hioide, ao processo estiloide e ao palato. Quando estes músculos se contraem, movimentam a língua em todas as direções. Os músculos intrínsecos, por sua vez, estão contidos inteiramente na língua, com origem e inserção nela e são responsáveis pela alteração de sua forma. (A descrição anatômica resumida desses músculos encontra-se na Parte 1.2: Anatomia funcional da boca)

A mucosa da língua adere fortemente a toda sua massa muscular e, dependendo da parte da língua que reveste, apresenta coloração, inervação e função diferentes.

A língua é dividida em dois terços anteriores (dorso, margens, face inferior e ápice) e um terço posterior (raiz da língua).

A face inferior da língua está voltada para diante e em contato com o soalho da boca, sendo que sua mucosa adere intimamente e de forma contínua com a musculatura lingual. Nesta face, encontramos na linha mediana uma prega mucosa, o freio lingual. Próximo da extremidade anterior e mais apical do freio lingual, notamos o aparecimento de outra prega mucosa com bordas onduladas e irregulares que recebe o nome de prega franjada. Ainda na porção do ápice da língua, estão as glândulas salivares menores (glândula lingual anterior).

Devido à translucidez da mucosa que recobre a face inferior da língua, podemos notar alguns vasos sanguíneos, principalmente a veia lingual.

A face dorsal da língua é dividida em terços. Os dois terços anteriores estão separados do terço posterior por um sulco em forma de V, o sulco terminal. Este sulco tem seu vértice mediano voltado para o terço posterior; nele encontramos um forame de profundidade variável, o forame cego.

O terço posterior da língua, que também é sua raiz, está voltado para a parte oral da faringe (orofaringe). Sua mucosa possiu bastantes saliências ou pequenas massas de tecido linfoide que recebem o nome de tonsila lingual. Ainda cobertas por esta mucosa, temos pequenas glândulas salivares linguais.

A raiz da língua limita-se com a epiglote por meio de pregas, sendo uma mediana, a prega glossoepiglótica mediana, e duas laterais, as pregas glossoepiglóticas laterais. Entre a prega mediana e as laterais, há uma depressão chamada valécula glossoepiglótica.

Espalhadas por todo dorso e bordas marginais da língua, temos as papilas linguais, denominadas de papilas circunvaladas, fungiformes e filiformes e folhadas. 
As papilas circunvaladas são as mais volumosas de todas, encontram-se enfileiradas à frente do sulco terminal, paralelas a ele. Cada papila circunvalada está mergulhada na mucosa lingual, apresenta a forma semelhante a um cogumelo, sendo circundada por um valo (daí o seu nome), no qual se abrem os ductos de glândulas linguais serosas cuja secreção mantém limpo este valo para a perfeita ação dos calículos gustatórios, que também estão aí presentes, e que são importantes receptores do gosto.

As papilas fungiformes são menos volumosas do que as circunvaladas, apresentam-se mais espaçadas na mucosa lingual, sendo lisas e avermelhadas. Apresentam calículos gustatórios e no indivíduo vivo podem ser visualizadas como pontos vermelhos luminosos.

Já as papilas filiformes, são longas e estreitas e estão distribuídas densamente por todo o dorso da língua. São estas papilas que dão um aspecto piloso à língua. Apresentam corpúsculos relacionados ao tato e não apresentam corpúsculos gustativos como as anteriores. (Figura 1.11)

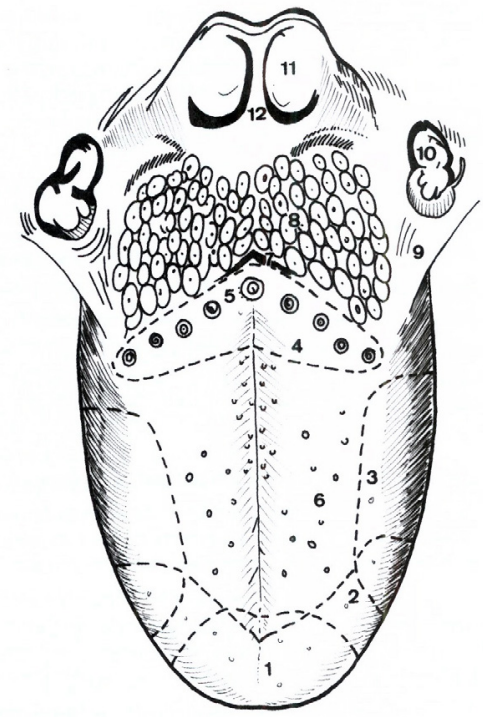

1. Doce

2. Salgado

3. Ácido

4. Amargo

5. Papilas circunvaladas

6. Papilas fungiformes

7. Sulco terminal

8. Tonsila lingual

9. Arco palatoglosso

10. Tonsila palatina

11. Valécula epiglótica

12. Prega glossoepiglótica mediana

Figura 1.11 - Língua, com demarcação das zonas do gosto por linhas interrompidas

\subsubsection{GLÂNDULAS SALIVARES}

A cavidade oral é mantida umedecida devido à saliva produzida e lançada nesta cavidade pelas glândulas salivares. Várias outras funções são atribuídas à saliva, como será visto mais adiante. 
As glândulas salivares são divididas, segundo o seu tamanho, em glândulas salivares menores e maiores. As glândulas salivares menores apresentam ductos excretores pequenos e segundo a sua localização topográfica são denominadas de: labiais, bucais, palatinas e linguais (como foi mencionado, quando da descrição da boca).

O grupo das glândulas salivares maiores, é formado por glândulas bilaterais de maior tamanho, volume, e que apresentam ductos excretores grandes e geralmente longos. Compreendem as glândulas parótidas, submandibulares e sublinguais.

A glândula parótida é a maior e a mais desenvolvida das glândulas salivares maiores, situa-se por trás da borda posterior do ramo da mandíbula e adiante do músculo esternocleidomastóideo. Acima mantém relações de proximidade com a articulação temporomandibular (ATM) e o meato acústico cartilagíneo e abaixo se estende até o nível do ângulo da mandíbula e a borda anterior do músculo esternocleidomastóideo. Profundamente estende-se até a faringe.

Esta glândula é formada por uma parte superficial e outra profunda, sendo unidas por um istmo. Devido a sua forma, ambas as partes da glândula abraçam as faces medial e lateral do ramo da mandíbula, onde estão inseridos os músculos pterigóideo medial e masseter, respectivamente. Anteriormente, a parte superficial, maior que a profunda, estende-se por sobre grande parte do músculo masseter, normalmente apresentando uma extensão anterior localizada abaixo do arco zigomático. Esta extensão anterior, por vezes destacada da glândula, recebe o nome de glândula parótida acessória.

A parte profunda da glândula é menor e localiza-se entre o músculo pterigóideo medial e os músculos que se relacionam com o processo estiloide (estilo-hióideo, estiloglosso e estilofaríngeo). No istmo, encontramos o nervo facial perfurando-o horizontalmente e a veia retromandibular verticalmente. No lobo profundo, temos a artéria carótida externa atravessando verticalmente a glândula, e a artéria maxilar emergindo daí.

O nervo facial (VII par craniano) ramifica-se entre as duas partes e seus ramos emergem pelas bordas da glândula parótida.

A glândula parótida está completamente envolvida por uma extensão da fáscia cervical chamada de fáscia parotídea. Esta fáscia se prende ao arco zigomático, ao processo estiloide e se fusiona com a fáscia massetérica e a fáscia do esternocleidomastóideo.

O ducto parotídeo emerge da borda anterior da glândula, cruza paralelamente o músculo masseter em direção a sua borda anterior, onde, após contorná-la, passa ao lado do corpo adiposo da bochecha, atravessa a superfície externa do músculo bucinador e abre-se no vestíbulo da boca, próximo ao segundo molar superior, numa saliência denominada papila parotídea. A glândula parótida é inervada pelo nervo glossofaríngeo (IX par craniano). 
A glândula submandibular apresenta uma forma ovoide ou de um corpo alongado, tendo um tamanho que corresponde à metade da parótida. Está localizada no compartimento ou triângulo submandibular formado em parte pela fáscia cervical, sendo que esta fáscia está frouxamente aderida à glândula. A superfície da glândula não é lisa, visto que é composta por um número variável de lóbulos unidos entre si por tecido conjuntivo.

A glândula submandibular pode ser dividida em duas porções: uma superficial, maior, arredondada e contínua com outra menor, que forma a porção profunda. Parte da porção superficial da glândula relaciona-se com a face medial do corpo da mandíbula, na fóvea submandibular, ficando desta forma oculta acima pela mandíbula. Já a parte visível da glândula é coberta pelo músculo platisma e pela pele, ocupando assim o importante triângulo submandibular. A porção medial da glândula relaciona-se com os músculos milo-hióideo e hioglosso, que formam entre si um espaço ou interstício pelo qual se tem acesso à região sublingual. É justamente por este espaço que passam o prolongamento profundo da glândula e o ducto submandibular. O ducto da glândula submandibular abre-se ao lado do freio da língua, na carúncula sublingual. A glândula recebe inervação do nervo facial (VII par craniano).

A glândula sublingual está em contato com a fóvea sublingual, depressão óssea localizada na face interna da mandíbula. Está localizada no soalho da boca e apresenta uma forma alongada e achatada. $\mathrm{Na}$ porção anterior e interna da mandíbula, as duas glândulas entram em contato uma com a outra, por suas extremidades anteriores.

Repousa sobre o músculo milo-hióideo e sua presença provoca uma saliência na mucosa do soalho da boca, a prega sublingual. Relaciona-se no compartimento sublingual com o ducto da glândula submandibular, nervo lingual e músculo genioglosso. Não apresentam ducto excretor único, mas sim aproximadamente uma dúzia de ductos sublinguais menores, que se abrem separadamente na prega sublingual. Algumas vezes podemos encontrar um ducto maior, chamado ducto sublingual maior, que se une ao ducto submandibular ou se abre na carúncula sublingual juntamente com o submandibular.

A glândula sublingual recebe inervação do nervo facial (VII par craniano) (Figura 1.12). 


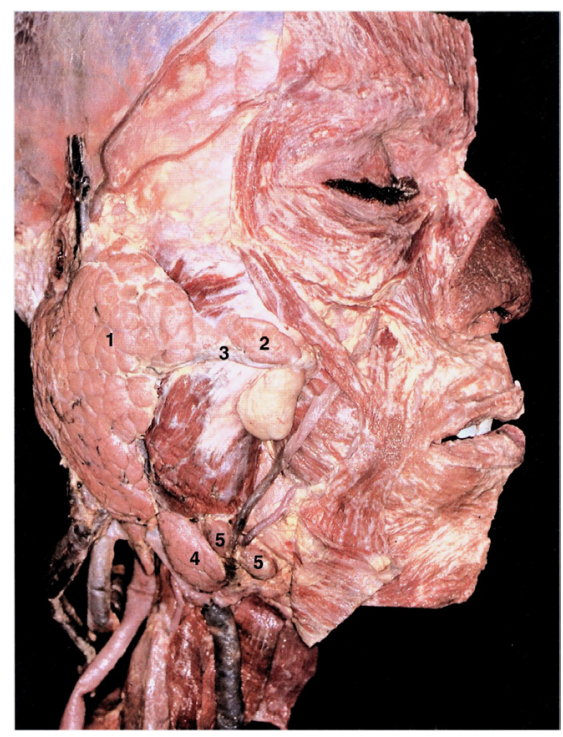

1. Glândula parótida

2. Glândula parótida acessória

3. Ducto parotídeo

4. Glândula submandibular

5. Linfonodo submandibular

Figura 1.12 - Peça anatômica com glândula parótida, ducto parotídeo, glândula submandibular e linfonodos submandibulares

\subsection{ANATOMIA FUNCIONAL DA BOCA}

\subsubsection{BOCA EM REPOUSO}

Quando em repouso, a boca é uma cavidade fechada, isto é, permanece com as suas aberturas anterior e posterior seladas pelos lábios, à frente, e pelo palato mole ou véu palatino, atrás. Este desce verticalmente sobre a porção posterior do dorso da língua como se fosse uma cortina (L. vellum, véu, cortina), fechando a cavidade da boca e separando-a da faringe.

Nos indivíduos que respiram pela boca, as aberturas anterior e posterior nunca estão cerradas e o ar passa por elas, provocando malposição dos dentes anteriores e espaços entre eles, elevação e estreitamento do palato (palato ogival) e ressecamento da mucosa da boca.

Ainda em posição de repouso, a ampla cavidade da boca é quase que totalmente preenchida pela língua e dentes. O ápice da língua fica em contato com a porção do palato atrás dos incisivos, as suas margens apoiam-se na face lingual dos dentes e a face inferior na mucosa do soalho da boca. As bochechas e os lábios reduzem qualquer espaço em razão do contato com os dentes anteriores e posteriores e, desta forma, o vestíbulo se anula pela redução do seu espaço. 
Neste estado habitual de repouso, os músculos mandibulares estão em contração mínima, contraídos apenas o suficiente para manter a postura da mandíbula, evitando assim que ela caia pela ação da gravidade (mecanismo reflexo proprioceptivo). A cabeça da mandíbula, também chamada côndilo, está alojada na fossa mandibular sem, entretanto, fazer pressão contra ela. Na realidade, ocupa uma posição anterossuperior em relação ao centro da fossa mandibular. Esta relação central é uma posição óssea (craniomandibular), independente de dentes, que corresponde à retrusão não forçada da mandíbula. Os lábios estão em leve contato, os dentes superiores e inferiores não se tocam e o espaço entre eles é chamado espaço funcional livre ou interoclusal.

É claro que certos fatores podem interferir com a constância dessa posição; por exemplo, a dor, o estresse físico e emocional e a postura da cabeça. A inclinação da cabeça para trás faz aumentar o espaço funcional livre e a inclinação para frente faz diminuir ou mesmo eliminar completamente esse espaço.

\subsubsection{DINÂMICA DA BOCA}

A passagem daquele estado estático, de descanso, para estados dinâmicos pode se restringir a pequenas contrações de músculos labiais, mas pode chegar a grandes movimentações da mandíbula. Quando esta se movimenta, todas as formações anatômicas da boca acompanham o movimento. Neste caso, todos os músculos revelam seu dinamismo, principalmente os músculos da mastigação, os quais geram os movimentos mandibulares, cujo fulcro é a articulação temporomandibular.

Articulação temporomandibular (ATM) - É a articulação entre os lados esquerdo e direito da mandíbula e os dois ossos temporais. Como única articulação sinovial da cabeça, possui todos os elementos constituintes de uma articulação dessa natureza, com exceção de ligamentos intracapsulares. Diferente das demais, no entanto, ela não é apenas uma articulação que movimenta ossos; é caracterizada também pela sua relação de interdependência com a oclusão dos dentes, o que a torna peculiar e funcionalmente complexa. Pelo exposto, como existe interdependência das articulações dos dentes e dos ossos, para se ter boa ATM é condição ter boa oclusão.

Outras peculiaridades da ATM, que a distinguem das demais articulações do corpo, são: "o revestimento de fibrocartilagem e não de cartilagem hialina; a cabeça da mandíbula cresce na superfície, sem cartilagem epifisial; as faces articulares são bastante discordantes; um disco articular se coloca entre as faces articulares; tem movimentos de rotação e de translação associados; impulsos proprioceptivos são gerados também no nível dos dentes e estruturas bucais" (CRUZ RIZZOLO \& MADEIRA, 2010). 
Os ossos maxilares e a ATM são adaptados para a mastigação molar. A área óssea dessa região dos dentes molares é mais apropriada para absorver e para escoar as forças mecânicas transmitidas dos dentes para ela. Grande parte dessa carga é transferida para a ATM, que a suporta bem. Admitindo-se, no entanto, que a mandíbula trabalhe tal qual uma alavanca, na mastigação incisiva, em que a distância (braço de resistência) entre os dentes em ação (resistência) e a ATM (fulcro) é bem mais longa, a carga transferida para a ATM é quase duas vezes maior, o que sobrecarrega e provoca alterações. É o que geralmente ocorre durante a vida dos indivíduos desdentados posteriores.

Nos casos de um dente entrar em contato com outro antes dos demais porque está "mais alto" (contato prematuro), a oclusão pode sobrecarregar os próprios dentes contactantes e aliviar a ATM. Assim, o côndilo passa a trabalhar numa posição anômala, o que é motivo de alteração da função muscular. Com esse funcionamento fora do normal, há um aumento do esforço dos músculos (potência), os quais, sobrecarregados, desencadeiam sintomas indesejáveis como a dor na cabeça, orelha e na própria articulação.

Palpando-se a dedo a ATM, à frente do trago da orelha, pode-se sentir a movimentação da cabeça da mandíbula durante a abertura e fechamento da boca. Os movimentos de protrusão, retrusão e lateralidade também podem ser percebidos pela mesma palpação ou então com o dedo dentro do meato acústico cartilagíneo.

Arcos dentais - Os dentes relacionam-se uns com os outros, por contiguidade, enfileirando-se em forma de arco. O arco superior, imóvel, espera a toque do arco inferior, que é móvel, para haver a chamada oclusão dental e daí a mastigação.

$\mathrm{Na}$ posição de oclusão, o arco dental superior, que é alguns milímetros mais largo e mais longo, envolve ou sobrepõe-se ao inferior, de modo que as bordas cortantes (incisais) dos seus incisivos e caninos ultrapassem e cubram as bordas incisais dos inferiores. Nos dentes posteriores, as cúspides dos superiores também ultrapassam as dos inferiores. A sobreposição é aumentada mais ainda porque os incisivos se apresentam inclinados para a vestibular (labial), com inclinação aproximada de $20^{\circ}$ nos superiores e de $12^{\circ}$ nos inferiores. Essa sobreposição ou trespasse horizontal é chamada na clínica odontológica como sobressaliência. No sentido vertical, o trespasse é conhecido como sobremordida. O trespasse vertical de mais de três milímetros resulta na indesejável mordida profunda. Há casos anômalos de incisivos superiores que não se sobrepõem aos inferiores; ao contrário, distanciam-se deles ocasionando um espaço que caracteriza a mordida aberta anterior. Outra aberração da oclusão é a mordida cruzada anterior, em que o trespasse horizontal e o vertical são invertidos, isto é, o arco dental inferior (todos os dentes superiores ou alguns deles) trespassa ou sobrepõe-se ao arco superior (MADEIRA \& CRUZ RIZZOLO, 2010). 
Os contatos entre os dentes vizinhos de cada arco são muito importantes para a manutenção do equilíbrio, e, na ausência desse contato, por fratura, cárie, agenesia ou extração, os dentes podem mudar de posição. Com dentes em malposição, principalmente aqueles que se inclinam em direção a falhas de dentes vizinhos, a desorganização aumenta pela força das oclusões sucessivas.

Mesmo em condições normais, porém, existem forças aplicadas sobre os dentes que podem alterar esse equilíbrio. É o caso daquelas exercidas pelos músculos da mastigação, as quais determinam o contato de maior ou menor intensidade entre os dentes antagonistas e que podem provocar, no sentido vertical, a intrusão do dente no alvéolo, isto é, o aprofundamento deste no interior da substância óssea esponjosa.

Outras forças ocorrem no sentido horizontal (direção vestíbulo-lingual). A musculatura dos lábios e das bochechas exerce pressão na face vestibular dos dentes anteriores e posteriores, que deve ser equilibrada pela pressão exercida pela língua na face lingual de todos os dentes. Se uma dessas forças é insuficiente para a manutenção do equilíbrio, haverá desvios dentais com prejuízo funcional e estético.

Oclusão dental - A oclusão acontece quando, ao se fazer a elevação da mandíbula através dos músculos elevadores, dá-se o contato entre os dentes antagonistas. Trata-se de um engrenamento dental em que cada dente de um arco deve ocluir com dois dentes do arco oposto; fazem exceção os incisivos centrais inferiores e os terceiros molares superiores, que ocluem unicamente com os seus homólogos antagonistas.

Em uma boa oclusão, as seguintes posições devem ocorrer: nos dentes anteriores, o terço incisal (livre) da face vestibular (labial) dos inferiores deve ocluir com o terço incisal da face lingual dos superiores e nos dentes posteriores, as cúspides vestibulares (bucais ou jugais) dos superiores também ultrapassam as dos inferiores. Estas, por sua vez, se encaixam nas fossetas e nos sulcos das faces oclusais (mastigatórias) dos dentes superiores e as cúspides linguais dos superiores também se encaixam nas fossetas e nos sulcos das faces oclusais dos dentes inferiores. Esse encaixe recíproco entre dentes antagonistas leva à posição de máxima intercuspidação, dando estabilidade aos dentes no arco inferior contra o arco dental superior e direcionando as forças provenientes da mastigação ao longo eixo dos dentes (MADEIRA \& CRUZ RIZZOLO, 2010).

A partir dessa relação estática entre os maxilares, que é a posição de máxima intercuspidação, inicia-se a oclusão dinâmica com seus repetidos movimentos de lateralidade, que caracterizam a mastigação molar. 


\subsubsection{MOVIMENTOS DA MANDÍBULA}

Desde a posição de repouso, os músculos elevadores da mandíbula podem se contrair, ao ponto de elevá-la até que haja o contato máximo dos dentes inferiores com os superiores. Ela fica assim na já referida posição de máxima intercuspidação, também conhecida como posição de oclusão central, com o maior número possível de contatos entre os dentes antagonistas. A manutenção desta posição requer dispêndio de esforço, pois os músculos masseter, pterigóideo medial e temporal, elevadores da mandíbula, devem permanecer contraídos (a descrição anatômica resumida dos músculos da mastigação e outros como os da língua, do palato e peribucais e demais músculos que movem a boca ou suas partes encontra-se em sequência próxima).

A boca em posição de oclusão é totalmente aberta com a participação do músculo pterigóideo lateral em trabalho comum com o músculo digástrico, este e também o gênio-hióideo e o milo-hióideo, que lhe são sinérgicos. O pterigóideo lateral é um músculo protrusor da mandíbula e o digástrico é retrusor. Apesar de serem antagônicos, estes músculos se ajudam e se completam em um trabalho simultâneo de rotação da mandíbula. Se eles se inserissem em um mesmo nível, um atrairia a mandíbula para frente e o outro para trás e com esse antagonismo anulariam qualquer possibilidade de movimento; ao contrário, haveria equilíbrio estático. Como, entretanto, o pterigóideo lateral se insere no alto da mandíbula e o digástrico bem abaixo, portanto em níveis bem diferentes, eles deixam de ser antagonistas para serem cooperadores no abaixamento da mandíbula (dupla força ou força conjugada).

Durante a abertura da boca, primeiro é realizado um movimento de rotação pura na ATM: a cabeça da mandíbula, na posição mais retrusiva e sem se deslocar para frente, gira em torno de um eixo horizontal transversal até o ponto em que se pode colocar um dedo entre os incisivos.

O segundo movimento, para continuar a abertura, é duplo: enquanto a rotação continua a ser realizada, a ela é associado um novo movimento, o de translação, em que a cabeça da mandíbula desliza para frente até ficar sob a eminência articular do osso temporal e isto pode ser notado pela palpação. Os dois movimentos em sequência provocam o abaixamento máximo da mandíbula, que desta vez permitirá a colocação de três dedos entre os dentes.

No movimento de retrusão puro, enquanto se mantém os dentes em leve contato, os côndilos da mandíbula protraída são trazidos de volta para a fossa mandibular por uma dupla de músculos retrusores da mandíbula que age sinergicamente - o digástrico e o temporal. Este se prende no alto do ramo da mandíbula e o digástrico na base do corpo, em nível bem mais baixo, portanto. Trabalhando 
em sinergia, um no alto e o outro em baixo, os músculos atraem toda a mandíbula para trás, numa translação condilar bilateral de forma equilibrada.

$\mathrm{Na}$ protrusão simétrica da mandíbula a partir da oclusão central ocorre o inverso: a ação passa a ser de ambos os pterigóideos laterais, músculos protrusores da mandíbula, que a transladam para frente. Quando se trata de protrusão assimétrica, ou movimento de lateralidade, apenas um dos pterigóideos laterais traciona o côndilo para frente. $\mathrm{O}$ côndilo oposto permanece em posição na fossa mandibular. Se o músculo em contração for o esquerdo, o movimento será o de translação unilateral direita ou lateralidade direita e vice-versa (MADEIRA, 2010).

\subsubsection{MASTIGAÇÃO}

As considerações feitas sobre arcos dentais, oclusão e movimentos da mandíbula facilitarão o entendimento do mecanismo da mastigação.

A partir da relação estática entre os maxilares, como na posição de máxima intercuspidação, os movimentos todos são realizados de maneira sincronizada e semiconsciente durante a mastigação. O padrão típico tem início com a incisão do alimento pelos dentes anteriores, se for necessário, e depois é levado pela língua aos dentes posteriores para ser triturado, ao mesmo tempo em que é insalivado.

A trituração dos alimentos começa com a realização dos chamados "movimentos excêntricos”, para a direita ou para a esquerda. As cúspides antagônicas em ação entram em atrito. Com o passar do tempo, esse atrito contínuo produz facetas de desgaste (desgaste fisiológico das cúspides), ou seja, áreas lisas devido ao desaparecimento gradual das elevações e dos sulcos. Naturalmente, os movimentos protrusivos, em que os incisivos inferiores deslizam contra a face lingual dos incisivos superiores, para cortar o alimento, também determinam desgastes (MADEIRA, 2010).

$\mathrm{Na}$ trituração, os ciclos mastigatórios se repetem até que o bolo alimentar possa ser deglutido. Se decompostos, esses ciclos consistiriam daqueles movimentos já citados de fechamento, lateralidade, abertura, combinados no final do ciclo com fortes movimentos de retrusão e protrusão. Na realidade, porém, há grande número de combinações de movimentos, de tal modo que as repetições dos ciclos mastigatórios são feitas de maneiras muito complexas. Os músculos não agem isoladamente, mas em associação.

Cada ciclo mastigatório dura menos de um segundo e é realizado unilateralmente. Durante a mastigação, os lados são trocados. Poucas são as vezes em que a mastigação é feita somente do lado esquerdo ou então do direito. 
A pressão do alimento pela língua contra o palato duro ocorre como sendo mais uma modalidade de mastigação, ou complementação da mastigação, mas que toma pequena parte no processo.

São quase todos os músculos envolvidos na mastigação inervados por meio dos ramos do nervo trigêmeo. As exceções ficam por conta do nervo facial (músculos da expressão facial e estilo-hióideo e ventre posterior do digástrico), nervo hipoglosso (músculos da língua e gênio-hióideo) e nervo vago, via plexo faríngeo (levantador do véu palatino, palatoglosso, palatofaríngeo e da úvula). São, pois, quatro nervos que determinam ações variadas, umas diferentes das outras, mas em perfeita coordenação ou sincronia. Trabalhando assim, sob um largo espectro de informações nervosas simultâneas e sincrônicas, são evitados movimentos extemporâneos ou fora de sequência que venham a ferir a bochecha ou morder a língua.

Citados como foram, nos movimentos gerais da mandíbula e no ato da mastigação, os músculos mandibulares serão também citados na fala, na sucção, na deglutição, por serem indispensáveis nessas ações. Até agora foram mencionados apenas os músculos que dão dinâmica à articulação da mandíbula. Somente com eles não seria possível realizar uma boa e completa mastigação. A movimentação do alimento dentro da boca depende da contração dos músculos da língua, do palato, das bochechas, dos lábios e do soalho da boca.

Por isso, todos esses músculos passam a ser agora sucintamente descritos.

\subsubsection{MÚSCULOS MANDIBULARES}

São os que se inserem na mandíbula, como os músculos da mastigação e os supra-hióideos.

Músculos da mastigação - Existem quatro músculos pares pertencentes ao grupo da mastigação, que têm o controle de quase todos os movimentos da mandíbula: três deles são elevadores (masseter, temporal e pterigóideo medial), um dos elevadores também é retrusor (temporal) e um é protrusor da mandíbula (pterigóideo lateral). Dois são superficiais e de fácil palpação (masseter e temporal) e os outros dois são profundos (pterigóideos medial e lateral). Ligam a mandíbula ao crânio, isto é, tomam origem no crânio (ponto fixo) e inserem-se na mandíbula, para movimentá-la (ponto móvel).

Atuam em grupo bem coordenado para produzir um movimento ou manter a postura. Deslocam a mandíbula para todas as direções (Quadro 1.1).

Músculos supra-hióideos - Compõem um grupo de músculos pares acima do osso hioide, que colaboram na mastigação: digástrico, milo-hióideo, gênio-hióideo e estilo-hióideo. Os três primeiros unem o osso hioide à mandíbula e o 
estilo-hióideo o une ao crânio. Fazem inserção (ponto móvel) no hioide, mas se este estiver imobilizado por músculos infra-hióideos e pelo estilo-hióideo, o milo-hióideo e o gênio-hióideo são capazes de fazer o ponto móvel na mandíbula e tracioná-la para trás. O digástrico, mais forte e mais independente, auxilia músculos da mastigação nos movimentos de abaixamento e retrusão da mandíbula. De um modo geral, os músculos supra-hióideos movem não apenas a mandíbula e o osso hioide, mas também o soalho da boca (Quadro 1.1). 
Quadro 1.1 - Resumo dos músculos da mastigação e supra-hióideos*

\begin{tabular}{|c|c|c|c|c|}
\hline MúSCULO & ORIGEM & INSERC̣ÃO & INERVAC̣ÃO & FUNC̣ÃO \\
\hline Masseter & $\begin{array}{l}\text { - Margem inferior do } \\
\text { osso zigomático (parte } \\
\text { superficial) e margem } \\
\text { inferior do arco zigomático } \\
\text { (parte profunda) }\end{array}$ & $\begin{array}{l}\text { - Nos dois terços inferiores } \\
\text { da face lateral do } \\
\text { ramo da mandíbula }\end{array}$ & $\begin{array}{l}\text { - Nervo massetéri- } \\
\text { co, ramo do man- } \\
\text { dibular (trigêmeo) }\end{array}$ & $\begin{array}{l}\text { - Levanta (com força) } \\
\text { a mandíbula }\end{array}$ \\
\hline Temporal & $\begin{array}{l}\text { - Soalho da fossa } \\
\text { temporal e super- } \\
\text { fície medial da } \\
\text { fáscia temporal }\end{array}$ & $\begin{array}{l}\text { - Bordas e face medial do } \\
\text { processo coronoide (crista } \\
\text { temporal) e borda anterior } \\
\text { do ramo da mandíbula }\end{array}$ & $\begin{array}{l}\text { - Nervos temporais } \\
\text { profundos, ramos } \\
\text { do mandibular } \\
\text { (trigêmeo) }\end{array}$ & $\begin{array}{l}\text { - Levanta a mandíbula } \\
\text { (mais velocidade } \\
\text { do que potência) } \\
\text { - Retrai a mesma com } \\
\text { a porção posterior }\end{array}$ \\
\hline $\begin{array}{l}\text { Pterigóideo } \\
\text { medial }\end{array}$ & - Fossa pterigóidea & $\begin{array}{l}\text { - Face medial da re- } \\
\text { gião do ângulo } \\
\text { da mandíbula }\end{array}$ & $\begin{array}{l}\text { - Nervo pterigóideo } \\
\text { medial, ramo do } \\
\text { mandibular (trigêmeo) }\end{array}$ & $\begin{array}{l}\text { - Eleva a mandíbula; } \\
\text { age como sinergista } \\
\text { do masseter }\end{array}$ \\
\hline $\begin{array}{l}\text { Pterigóideo } \\
\text { lateral }\end{array}$ & $\begin{array}{l}\text { - Face lateral de lâ- } \\
\text { mina lateral do } \\
\text { processo pterigoi- } \\
\text { de e superfície in- } \\
\text { fratemporal da } \\
\text { asa maior do esfe- } \\
\text { noide }\end{array}$ & $\begin{array}{l}\text { - Fóvea pterigóidea } \\
\text { e margem anterior } \\
\text { do disco da ATM }\end{array}$ & $\begin{array}{l}\text { - Nervo pterigóideo } \\
\text { lateral, ramo do } \\
\text { mandibular (trigêmeo) }\end{array}$ & $\begin{array}{l}\text { - Protrai (e com os } \\
\text { digástricos abaixa) a } \\
\text { mandíbula pela con- } \\
\text { tracão bilateral } \\
\text { simultânea } \\
\text { - Movimenta para um } \\
\text { dos lados pela } \\
\text { contracacão unilateral } \\
\text { - Estabiliza o disco } \\
\text { articular }\end{array}$ \\
\hline Digástrico & - Incisura mastóidea & $\begin{array}{l}\text { - Fossa digástrica } \\
\text { - } 0 \text { tendão intermédio } \\
\text { prende-se pela alça } \\
\text { digástrica (indiretamente) } \\
\text { a0 osso hioide }\end{array}$ & $\begin{array}{l}\text { - Ventre anterior: nervo } \\
\text { milo-hióideo, ramo } \\
\text { do alveolar inferior, } \\
\text { que é ramo do } \\
\text { nervo mandibular } \\
\text { - Ventre posterior: ramo } \\
\text { digástrico, do nervo facial }\end{array}$ & $\begin{array}{l}\text { - Retrai (e com os } \\
\text { pterigóideos laterais } \\
\text { abaixa) a mandibula }\end{array}$ \\
\hline Estilo-hióideo & - Processo estiloide & - Osso hioide & $\begin{array}{l}\text { - Ramo estilo-hióideo } \\
\text { do nervo facial }\end{array}$ & $\begin{array}{l}\text { - Puxa o hioide para } \\
\text { cima e para trás }\end{array}$ \\
\hline Milo-hióideo & - Linha milo-hióidea & $\begin{array}{l}\text { - Rafe milo-hióidea } \\
\text { e corpo do hioide }\end{array}$ & $\begin{array}{l}\text { - Nervo milo-hióideo, } \\
\text { ramo do alveolar } \\
\text { inferior, que é ramo do } \\
\text { mandibular (trigêmeo) }\end{array}$ & $\begin{array}{l}\text { - Eleva o soalho da boca } \\
\text { hioide e língua Protrai } \\
\text { o hioide ou retrai (e } \\
\text { abaixa) a mandíbula }\end{array}$ \\
\hline Gênio-hióideo & $\begin{array}{l}\text { - Espinha mentonia- } \\
\text { na inferior }\end{array}$ & - Corpo do hioide & $\begin{array}{l}\text { - Primeiro nervo } \\
\text { cervical, através do } \\
\text { nervo hipoglosso }\end{array}$ & $\begin{array}{l}\text { - Protrai o hioide ou } \\
\text { retrai (e abaixa) } \\
\text { a mandíbula }\end{array}$ \\
\hline
\end{tabular}

\footnotetext{
* Este Quadro 1.1, bem como os próximos Quadros 1.2 e 1.3, foram modificados dos originais que se encontram nos livros de dois dos autores deste capítulo, CRUZ RIZZOLO \& MADEIRA (2010).
} 
Músculos da língua - A língua se mexe para qualquer lado, alcançando todos os dentes, todo o vestíbulo e grande parte do palato e do soalho da boca. Seu contato com essas partes serve para explorá-las e limpá-las e para deslocar o bolo alimentar repetidamente e a misturá-lo com saliva para ser deglutido. Além disso, desempenha importante papel na deglutição e na fala.

Esses extensos deslocamentos dependem da grande quantidade de músculos que compõem o órgão e que serão resumidos. Os maiores são aqueles extrínsecos, cujas origens situam-se em ossos próximos e estendem-se até a língua para realizar seus movimentos mais extensos. São apresentados resumidamente no Quadro 1.2 .

Os demais são os músculos intrínsecos, de movimentos menores, que modificam a forma da língua. Estão confinados à própria língua, não se ligando a estruturas vizinhas. São constituídos por feixes dispostos longitudinalmente músculos longitudinais superior e inferior - que ao se contraírem encurtam a língua, tornando-a mais espessa e mais larga, e levam sua ponta para cima e para trás. Outros são dispostos transversalmente (músculo transverso) e verticalmente (músculo vertical). Se o grupo de fibras transversais se contrai, a língua se estreita, se espessa e se alonga. Se é o grupo de fibras verticais que entra em ação, a língua fica mais larga e mais longa. As formas e as posições variadas são tomadas pelas ações combinadas dos músculos (CRUZ RIZZOLO \& MADEIRA, 2010; MADEIRA, 2010).

Músculos do palato - $\mathrm{O}$ palato mole tem um pequeno esqueleto fibroso que se prende na borda livre da lâmina horizontal do osso palatino. É a aponeurose palatina, uma expansão da inserção do músculo tensor do véu palatino, um dos músculos do palato. Todos os demais músculos (levantador do véu palatino, palatoglosso, palatofaríngeo e o músculo da úvula) fixam-se na aponeurose palatina. Os músculos atuam em conjunto e suas denominações já indicam suas principais funções. O palatoglosso e o palatofaríngeo, por se estenderem do palato à língua e à faringe, tanto movimentam a área de origem, quanto a de inserção (Quadro 1.2). 
Quadro 1.2 - Resumo dos músculos da língua e do palato

\begin{tabular}{|c|c|c|c|c|}
\hline MúsCULO & ORIGEM & INSERC̣ÃO & INERVAC̣ÃO & FUNÇÃO \\
\hline Intrínsecos da língua & Língua & Língua & Nervo Hipoglosso & $\begin{array}{l}\text { Provocam formas e } \\
\text { posiçōes variadas }\end{array}$ \\
\hline Genioglosso & $\begin{array}{l}\text { Espinha mentoniana } \\
\text { superior }\end{array}$ & $\begin{array}{l}\text { Ápice, dorso e raiz } \\
\text { da língua }\end{array}$ & Nervo hipoglosso & $\begin{array}{l}\text { Abaixa a língua. } \\
\text { Fibras médias e } \\
\text { posteriores protraem. } \\
\text { Fibras anteriores } \\
\text { retraem a ponta }\end{array}$ \\
\hline Hioglosso & $\begin{array}{l}\text { Corno maior e corpo } \\
\text { do osso hioide }\end{array}$ & $\begin{array}{l}\text { Aspecto lateral } \\
\text { da língua }\end{array}$ & Nervo hipoglosso & $\begin{array}{l}\text { Abaixa e ajuda a } \\
\text { retrair a língua }\end{array}$ \\
\hline Estiloglosso & Processo estiloide & $\begin{array}{l}\text { Aspecto postero- } \\
\text { lateral da lingua }\end{array}$ & Nervo hipoglosso & $\begin{array}{l}\text { Retrai e levanta } 0 \\
\text { lado da língua }\end{array}$ \\
\hline Palatoglosso & Aponeurose palatina & $\begin{array}{l}\text { Aspecto postero- } \\
\text { lateral da língua }\end{array}$ & Nervo glossofaríngeo & $\begin{array}{l}\text { Eleva a língua ou } \\
\text { abaixa o palato } \\
\text { Ajuda a estreitar } 0 \\
\text { istmo das fauces }\end{array}$ \\
\hline Palatofaríngeo & Aponeurose palatina & $\begin{array}{l}\text { Superfície postero- } \\
\text { lateral da faringe }\end{array}$ & Nervo vago & $\begin{array}{l}\text { Eleva a faringe e } \\
\text { estreita } 0 \text { istmo } \\
\text { das fauces }\end{array}$ \\
\hline $\begin{array}{l}\text { Tensor do véu } \\
\text { palatino }\end{array}$ & Fossa escafoide & $\begin{array}{l}\text { Contorna o hâmulo } \\
\text { pterigóideo e } \\
\text { insere-se na } \\
\text { aponeurose palatina }\end{array}$ & $\begin{array}{l}\text { Ramo do nervo } \\
\text { mandibular do } \\
\text { trigêmeo }\end{array}$ & $\begin{array}{l}\text { Torna tenso } 0 \\
\text { palato mole }\end{array}$ \\
\hline $\begin{array}{l}\text { Levantador do } \\
\text { véu palatino }\end{array}$ & $\begin{array}{l}\text { Aspecto inferior da } \\
\text { parte petrosa do } \\
\text { temporal }\end{array}$ & Aponeurose palatina & Nervo vago & Eleva o palato mole \\
\hline Da úvula & Espinha nasal posterior & Mucosa da úvula & Nervo vago & Movimenta a úvula \\
\hline
\end{tabular}

Tal como ocorre com os da língua, outros músculos também intervêm na mastigação. É o caso do milo-hióideo, já descrito, que, além de ajudar na movimentação da mandíbula, também eleva o assoalho da boca para facilitar a mastigação e a deglutição. São, no entanto, alguns músculos da expressão facial que agem mais na mastigação.

Os músculos peribucais não apenas mantêm os lábios selados, como também ajudam a esvaziar o vestíbulo a fim de que o alimento seja cortado ou dilacerado entre os dentes. Continuamente, os bucinadores fazem o alimento retornar do vestíbulo para nova trituração entre os molares. 
Vamos, pois, relembrar a anatomia desses músculos.

Músculos da expressão facial (somente os peribucais) - Relacionam-se com a alimentação (recepção do alimento, mastigação, sucção), fonação e piscar de olhos, além é claro, com as manifestações faciais das emoções e dos sentimentos. A contração deles move a área da cútis à qual estão fixados, produzindo depressões em forma de linha (de fossa também) perpendiculares à direção das fibras dos músculos, que com o tempo se transformam em pregas ou rugas permanentes. Os feixes de fibras de um músculo são muitas vezes unidos aos de outro e nos locais de inserção é comum estarem entrelaçados.

Por se tratar de uma abordagem sobre a boca, trataremos apenas dos músculos peribucais, aqueles que circunscrevem a rima da boca ou se dispõem em torno dos lábios.

Só um deles é constritor dos lábios (músculo orbicular da boca); os demais são dilatadores (músculos levantador do lábio superior, levantador do lábio superior e da asa do nariz, zigomático menor, levantador do ângulo da boca, zigomático maior, risório, bucinador, abaixador do ângulo da boca, abaixador do lábio inferior, mentoniano e platisma). Suas características fazem parte do resumo expresso no Quadro 1.3, a seguir. 


\section{Quadro 1.3 - Resumo dos músculos da expressão facial (somente os peribucais)}

\begin{tabular}{|c|c|c|c|}
\hline Orbicular da boca & $\begin{array}{l}\text { Quase todo cutâneo; fóveas } \\
\text { incisivas da maxila e mandíbula }\end{array}$ & $\begin{array}{l}\text { Pele e mucosa dos } \\
\text { lábios; septo nasal }\end{array}$ & $\begin{array}{l}\text { Comprime os lábios contra } \\
\text { os dentes; fecha a boca; } \\
\text { protrai os lábios }\end{array}$ \\
\hline Levantador do lábio superior & Margem infra-orbital & Lábio superior & Levanta o lábio superior \\
\hline $\begin{array}{l}\text { Levantador do lábio superior } \\
\text { e da asa do nariz }\end{array}$ & $\begin{array}{l}\text { Processo frontal } \\
\text { da maxila }\end{array}$ & $\begin{array}{l}\text { Asa do nariz e } \\
\text { lábio superior }\end{array}$ & $\begin{array}{l}\text { Levanta o lábio superior e a } \\
\text { asa do nariz (dilata a narina) }\end{array}$ \\
\hline Zigomático menor & Osso zigomático & Lábio superior & Levanta o lábio superior \\
\hline Levantador do ângulo da boca & Fossa canina da maxila & Ângulo da boca & Levanta 0 ângulo da boca \\
\hline Zigomático maior & Osso zigomático & Ângulo da boca & $\begin{array}{l}\text { Levanta e retrai } 0 \\
\text { ângulo da boca }\end{array}$ \\
\hline Risório & $\begin{array}{l}\text { Pele da bochecha e } \\
\text { fáscia massetérica }\end{array}$ & Ângulo da boca & Retrai o ângulo da boca \\
\hline Bucinador & $\begin{array}{l}\text { Processos alveolares da maxila } \\
\text { e da mandíbula na região molar; } \\
\text { ligamento pterigomandibular }\end{array}$ & Ângulo da boca & $\begin{array}{l}\text { Distende a bochecha e a } \\
\text { comprime de encontro aos } \\
\text { dentes; retrai o ângulo da bocc }\end{array}$ \\
\hline Abaixador do ângulo da boca & $\begin{array}{l}\text { Base da mandíbula (da } \\
\text { região molar ao tubér- } \\
\text { culo mentoniano) }\end{array}$ & Ângulo da boca & Abaixa o ângulo da boca \\
\hline Abaixador do lábio inferior & $\begin{array}{l}\text { Base da mandíbula, acima } \\
\text { da origem do abaixador } \\
\text { do ângulo da boca }\end{array}$ & Lábio inferior & Abaixa o lábio inferior \\
\hline Mentoniano & $\begin{array}{l}\text { Fossa mentoniana acima } \\
\text { do tubérculo mentoniano }\end{array}$ & Pele do mento & $\begin{array}{l}\text { Enruga a pele do mento; } \\
\text { everte o lábio inferior }\end{array}$ \\
\hline Platisma & Base da mandíbula & Pele do pescocto & Enruga a pele do pescoço \\
\hline
\end{tabular}

\subsubsection{DEGLUTIÇÃO}

Durante a mastigação, as secreções das glândulas salivares umedecem, dissolvem, digerem parcialmente (com enzimas que iniciam a quebra química de alimentos contendo amido) e unem as partículas do alimento, formando massa única. A quantidade de secreção varia de acordo com o tipo de alimento; será maior se o alimento for seco. Pode-se estimar a produção em cerca de um litro ou pouco mais por dia (MARIEB \& HOEHN, 2009). 
A saliva contém substâncias que inibem atividade bacteriana e que reduzem o tempo de coagulação sanguínea. Seu pH é ligeiramente ácido; quando a acidez diminui muito pode haver depósito de carbonato de cálcio e fosfato de cálcio sobre os dentes, formando cálculos também conhecidos por tártaro (SCOTT \& SYMONS, 1964).

Completada a mastigação, as partículas do alimento, misturadas à saliva, são juntadas sobre o dorso da língua como um corpo único, o bolo alimentar. Neste ponto ele está pronto para ser deglutido a um só tempo. Isto se dá quando a língua o pressiona contra o palato e força seu deslocamento para trás.

Para chegar ao esôfago, o bolo tem de atravessar o istmo das fauces, ganhar a faringe e atravessar o local da passagem de ar do nariz à laringe, que é temporariamente fechada no momento em que o bolo alimentar se desloca rapidamente (menos de um segundo) em direção ao esôfago. Portanto, durante a deglutição, os movimentos respiratórios são suspensos.

O fechamento da laringe dá-se pela elevação da laringe, ao mesmo tempo em que a cartilagem epiglote é movimentada para trás pela ação da língua e dos músculos aritenóideo oblíquo, ariepiglótico e tireoepiglótico para selar o ádito da laringe. Previne assim a entrada de sólidos e líquidos nas vias respiratórias. O bolo desliza sobre a face posterior da epiglote e o líquido de cada lado da epiglote em direção ao recesso piriforme entre a faringe e o lado da laringe.

Uma série de músculos entra em ação durante a deglutição. Os músculos intrínsecos da língua equilibram o bolo alimentar no dorso da língua. Os músculos elevadores da mandíbula se contraem para colocar os dentes em oclusão. Estes são músculos fixadores que manterão a mandíbula imóvel, enquanto outros músculos trabalham para impelir o bolo alimentar para trás. Fixadores porque formam uma base fixa, a partir da qual os demais músculos agem (tente engolir com a boca aberta para ver como é difícil e descômodo). Ainda neste momento preparatório que antecede a deglutição, os lábios se fecham, a poder do músculo orbicular da boca, e o ápice da língua fica em contato com o palato duro, logo atrás dos incisivos.

Ocorre então que a língua precisa ser erguida fortemente contra o palato duro e mole. Os músculos linguais que participam dessa elevação são o estiloglosso, o palatoglosso e os intrínsecos. Mas, também concorre para isso o músculo milo-hióideo, que eleva todo o soalho da boca e com ele a língua, ajudado pelo digástrico e pelo estilo-hióideo. Nesta posição, a língua impulsiona o bolo alimentar, com pressão de frente para trás iniciada no ápice e progredindo pelo corpo, até o bolo se deslocar para a faringe. Toda essa movimentação é feita de maneira voluntária.

Os músculos palatinos também agem para selar a parte nasal da faringe. Isto é feito pelo elevador e pelo tensor do véu palatino que, ao levantar e distender o 
palato mole, formam um diafragma bem fechado entre as partes nasal e oral da faringe, ajudados pela contração das fibras mais superiores do constritor superior da faringe. Desta maneira, o bolo alimentar fica impedido de adentrar a parte nasal da faringe (MOORE, 1994; JOHNSON \& MOORE, 1999).

"Se uma pessoa ri durante este estágio, os músculos do palato mole relaxam e podem permitir a entrada de algum alimento na porção nasal da faringe. Nesses casos, o alimento é expelido através do nariz, especialmente se for líquido” (MOORE, 1994).

A faringe é levantada, junto com a laringe, pelos músculos estilofaríngeo e palatofaríngeo de encontro à epiglote que, como já visto, se movimentam para fechar a passagem de ar à laringe e evitar a invasão de fragmentos de comida.

Assim que o bolo alimentar chega à parte oral da faringe, pressiona certas áreas mucosas, cuja inervação é estimulada para deflagrar reflexos. Iniciado o reflexo, os músculos constritores da faringe contraem-se uniforme e sucessivamente, de cima para baixo, impelindo o bolo ao esôfago.

\subsubsection{SUCÇÃO}

Ao sugar, o lactente usa músculos da mastigação para movimentar a mandíbula, os peribucais (da expressão facial), principalmente o orbicular da boca, o bucinador e o mentoniano, e também aqueles utilizados na deglutição. Associados a movimentos da língua, esses músculos em ação promovem uma pressão negativa na cavidade da boca, o que facilita a transferência do leite do mamilo ou da chupeta da mamadeira para a boca, a qual percorre rapidamente para ser deglutido por meio do mecanismo já conhecido.

As gengivas de maxilar e mandíbula pressionam o mamilo ao mesmo tempo em que a língua toma uma forma acanalada (um sulco ao longo dela) e fica sob ele, distendendo-o e apertando-o contra o palato, cujos músculos também se contraem e vedam o istmo das fauces. Estas ações musculares todas criam o vácuo próprio da sucção. O leite escorre e a boca cheia é logo esvaziada com a deglutição. Enquanto isto o mamilo é liberado, retoma sua forma normal, até o início de novo ciclo.

A sucção poderia introverter a bochecha, trazendo-a para entre as gengivas. Isto não acontece porque o músculo bucinador se contrai e impede a introversão, assistido pela bem desenvolvida massa (nas criancinhas) do corpo adiposo da bochecha.

$\mathrm{Na}$ sucção do leite materno, a respiração é dificultada e completamente suspensa durante a deglutição. $\mathrm{Na}$ sucção de líquido por meio de um canudinho, pode-se respirar pelo nariz porque a passagem da boca para a faringe fica fechada (BOILEAU GRANT \& BASMAJIAN, 1965). 
A regurgitação e a eructação, que frequentemente acompanham o ato de amamentar, decorrem da ingestão de ar quando a sucção é muito rápida o quando o contato (selamento) entre os lábios e a mama é quebrado.

"A fenda palatina dificulta a sucção porque o ar recolhido através da fenda impede a formação de vácuo dentro da boca” (BOILEAU GRANT \& BASMAJIAN, 1965).

\subsubsection{FALA}

Os sons são produzidos pela laringe (fonação) durante a expiração, mas modificam-se quando o ar passa pela boca e/ou pelo nariz. Durante a fala normal, o ar escapa livremente pela cavidade da boca na produção das vogais. Mesmo assim, o grau de abertura da boca determina maior ou menor ressonância da voz, com variação do timbre. Este pode ser mais aberto ou mais fechado nas vogais, definindo a entonação própria de cada uma delas.

Boca aberta totalmente, no entanto, inclui a elevação do palato mole; se estiver abaixado, parte do ar é desviada pela cavidade nasal, provocando, como efeito acústico, o tom anasalado da voz.

Ligeira e rápida obstrução do ar pelo palato mole ocorre na emissão de consoantes. Contudo, maior obstrução é dada pela língua, dentes e lábios, verdadeiros responsáveis pela produção das letras consoantes, com exceção do fonema H. O impedimento temporário é breve, mas suficiente para a formulação das consoantes chamadas labiais ou bilabiais (M, P, B), labiodentais $(\mathrm{F}, \mathrm{V})$, linguodentais (D, T), linguopalatinas (Z, Q, G).

Assim, o som é emitido quando o ar expelido passa pela laringe em fluxos oscilantes (e não uniforme como na respiração normal) determinados pela adução/ abdução das pregas vocais em frequências variáveis e em maior ou menor volume, pressão e rapidez, que regulam a sonoridade. Depois, o som é articulado por barreiras naturais que se abrem ou se fecham acionadas pelos músculos do palato, da língua, da boca e, obviamente, os músculos da mastigação. A estes músculos devem ser adicionados os do tórax e da laringe, onde a fonação se inicia.

\subsection{INERVAC̣ÃO DA BOCA}

A boca é inervada fundamentalmente por quatro pares de nervos cranianos, os nervos trigêmeo (V par), facial (VII par), glossofaríngeo (IX par) e hipoglosso (XII par), e em menor medida pelo nervo vago (X par). O conjunto fornece inervação motora para toda a musculatura da região mandibular, bucal, peribucal, 
da língua, palato e da faringe, assim como inervação sensitiva e autonômica, esta última destinada basicamente à inervação glandular.

\subsubsection{NERVO TRIGÊMEO (V)}

Desses quatro pares, o n. trigêmeo[1] é o que tem maior participação. É um nervo misto, de componentes motores e sensitivos. Surge do encéfalo (origem aparente) pela região anterolateral da ponte. Neste local podem ser observados dois troncos. O tronco mais calibroso representa a raiz sensitiva, que traz toda a informação somestésica da face. O mais fino contém fibras motoras. Os dois troncos alcançam a porção petrosa do temporal, na qual se encontra uma pequena depressão, a impressão trigeminal, sobre a qual se localiza o gânglio trigeminal. O gânglio contém os corpos celulares dos neurônios sensitivos primários. Os axônios distais desses neurônios formam as três divisões do n. trigêmeo, que trazem informação sensorial da face, mucosa bucal, gengiva, dentes etc. Os axônios proximais penetram o tronco encefálico e fazem sinapse em núcleos trigeminais sensitivos. O componente motor origina-se de motoneurônios localizados dentro do tronco encefálico. Estes formam um núcleo denominado núcleo motor do n. trigêmeo. Deles partem axônios que formarão a raiz motora e, posteriormente, nervos motores para os músculos da mastigação, entre outros.

A partir do gânglio trigeminal, os prolongamentos periféricos se agrupam formando três grandes nervos: o oftálmico (ou V1), responsável por trazer ao encéfalo informação somestésica do terço superior da face; o maxilar (ou V2) com a mesma função que o V1, mas responsável pela sensibilidade do terço médio da face, e finalmente o n. mandibular (ou V3) que, além levar ao encéfalo informação sensorial do terço inferior da face, fornece fibras motoras para os músculos da mastigação. Assim, a boca é inervada pela segunda e terceira divisão do V par craniano[2].

\subsubsection{NERVO FACIAL (VII)}

O VII par craniano fornece à boca inervação motora, sensorial e autonômica. $\mathrm{Na}$ sua origem aparente no sulco bulbopontino podem ser observadas duas raízes nervosas ( $\mathrm{n}$. facial e n. intermédio) que penetram a parte petrosa do temporal através do meato acústico interno, onde se fundem em tronco único (motivo deste nervo também ser denominado facial-intermédio). Dentro do osso temporal, esse tronco se situa no canal facial até sua terminação no forame estilomastóideo. Nesse percurso, ele muda abruptamente de direção, formando o joelho do nervo facial, local onde se expande para formar o gânglio geniculado. Nesse gânglio estão os corpos neuronais da raiz sensitiva, ou seja, do n. intermédio, nervo que 
também contém as fibras parassimpáticas que se relacionam com os gânglios pterigopalatino e submandibular.

As fibras motoras do VII par abandonam a porção petrosa do temporal pelo forame estilomastóideo. Suas primeiras ramificações motoras se dirigem para o ventre posterior do m. digástrico e para o m. estilo-hióideo. Ao alcançar a glândula parótida, divide-se em vários ramos os quais se comunicam para formar o plexo intraparotídeo. Os ramos terminais são conhecidos como temporais, zigomáticos, bucais, marginal da mandíbula e cervical e destinam-se aos músculos da expressão facial situados nas regiões indicadas pelos próprios nomes dos ramos nervosos.

O componente sensorial do n. facial é responsável pela sensibilidade gustativa dos dois terços anteriores da língua, onde suas fibras terminam em conexão com as papilas ali existentes (lembrar que a sensibilidade somestésica está relacionada com o n. lingual, ramo do $\mathrm{V}$ par), e um pequeno contingente que capta informação somestésica da orelha externa. A partir das papilas linguais, delicados filetes nervosos unem-se formando o n. corda do tímpano. Este se associa ao n. lingual, ramo do n. mandibular (do $\mathrm{V}$ par), compartilhando um só tronco nervoso que só se separa na fossa infratemporal. Aí ele se desprende do n. lingual e atravessa a fissura petrotimpânica para penetrar o osso temporal. Dentro desse osso as fibras gustativas percorrem o canal facial, atravessam o meato acústico interno e penetram o tronco encefálico, fazendo sinapse no núcleo do trato solitário, onde a informação gustativa começa a ser processada.

O n. corda do tímpano contém fibras parassimpáticas também, que se originam no núcleo salivatório superior no tronco do encéfalo. Próximo ao gânglio submandibular localizado no soalho da cavidade bucal, essas fibras pré-ganglionares se separam do tronco principal e fazem sinapse dentro do gânglio com os neurônios pós-ganglionares, cujos axônios inervam as glândulas salivares sublingual e submandibular, linguais e lingual anterior.

Outra parte do componente parassimpático do VII par origina-se também do núcleo salivatório superior. Fibras pré-ganglionares juntam-se ao n. intermédio formando posteriormente o n. petroso maior. Junto com o n. petroso profundo -que possui fibras simpáticas- formam o n. do canal pterigóideo, o qual alcança a fossa pterigopalatina. Dentro dessa fossa, as fibras pré-ganglionares parassimpáticas fazem sinapse com os neurônios pós-ganglionares localizados no gânglio pterigopalatino. Fibras desses neurônios inervam a glândula lacrimal, glândulas salivares palatinas e glândulas mucosas da cavidade nasal, associando-se geralmente a fibras trigeminais destinadas a essas regiões. 


\subsubsection{NERVO GLOSSOFARÍNGEO (IX)}

Semelhante ao VII par craniano, o n. glossofaríngeo apresenta componentes motores, sensoriais e autonômicos. Tem origem aparente no bulbo e emerge do crânio após atravessar o forame jugular, junto com os nervos vago e acessório. Nesse nível, ele se expande em dois gânglios (superior e inferior), onde se localizam os corpos celulares de suas fibras aferentes (gustativas e somestésicas). As fibras motoras inervam o m. estilofaríngeo, e junto com fibras do n. vago os músculos constritores da faringe e o m. palatofaríngeo. O componente sensorial capta informação somestésica da tonsila palatina, mucosa faríngea e terço posterior da língua, e também informação gustativa dessa região posterior da língua e adjacências. Já o componente parassimpático origina-se no núcleo salivatório inferior no tronco encefálico. Fibras pré-ganglionares percorrem o n. timpânico e depois formam o n. petroso menor, alcançando o gânglio ótico. Aí ocorre a sinapse com os neurônios parassimpáticos pós-ganglionares, cujas fibras incorporam-se ao n. auriculotemporal (do V par) para assim inervar a glândula parótida.

\subsubsection{NERVO HIPOGLOSSO (XII)}

É o nervo motor da musculatura da língua. Origina-se no núcleo motor do n. hipoglosso, no bulbo, e dele originam-se os axônios que formam o nervo. Após atravessar o canal do hipoglosso, atinge o pescoço e posteriormente a língua, dando ramos para os músculos extrínsecos e intrínsecos. 


\begin{tabular}{|c|c|c|}
\hline \multicolumn{2}{|l|}{ NERVO } & \multirow{2}{*}{$\begin{array}{l}\text { FUNÇÃO PRINCIPAL (EM RELAC̣ÃO } \\
\text { Á INERVAC̣ÃO DA BOCA) } \\
\text { - Sensibilidade geral de pele e mucosa. }\end{array}$} \\
\hline N. trigêmeo (V) & Componente sensitivo & \\
\hline & Componente motor & - Motricidade para mm da mastigação \\
\hline \multirow[t]{3}{*}{ N. facial-intermédio (VII) } & Componente sensitivo & - Sensibilidade gustativa dos dois terços anteriores da língua \\
\hline & Componente motor & - Motricidade para os mm da expressão facial \\
\hline & Componente autonômico & $\begin{array}{l}\text { - Inervação parassimpática das glândulas submandibular, sublingual, e outras } \\
\text { pequenas glândulas salivares (via gânglios submandibular e pterigopalatino) }\end{array}$ \\
\hline \multirow[t]{4}{*}{ N. glossofaríngeo (IX) } & \multirow[t]{2}{*}{ Componente sensitivo } & - Somestésica: tonsila palatina, mucosa faríngea, base da língua \\
\hline & & - Gustativa: terço posterior da língua e áreas vizinhas \\
\hline & Componente motor & $\begin{array}{l}\text { - m estilofaríngeo } \\
\text { - mm constritores da faringe (+ n. vago) } \\
\text { - m palatofaríngeo (+ n. vago) }\end{array}$ \\
\hline & Componente autonômico & - Inervação parassimpática da gl.parótida (via gânglio ótico) \\
\hline \multirow[t]{3}{*}{ N. Vago $(X)^{\star}$} & Componente sensitivo & $\begin{array}{l}\text { - Orelha externa e meato acústico } \\
\text { - Mucosa da parte inferior da faringe } \\
\text { - Mucosa da laringe }\end{array}$ \\
\hline & Componente motor & $\begin{array}{l}\text { - Musculatura faríngea (plexo faríngeo junto com o IX par) } \\
\text { - Musculatura do palato mole (m. levantador do véu palatino e m. da úvula) }\end{array}$ \\
\hline & Componente autonômico & - Sem inervação na face (vísceras torácicas e abdominais) \\
\hline N. hipoglosso (XII) & Componente motor & - Músculos extrínsecos e intrínsecos da língua \\
\hline
\end{tabular}

*Em razão de sua pequena participação na inervação da boca, a descrição do n. vago foi omitida deste texto.

\subsubsection{OS NÚCLEOS TRIGEMINAIS E A SENSIBILIDADE SOMÁTICA}

O aparelho mastigador representa uma unidade na qual estruturas periféricas estão intrinsecamente associadas com estruturas centrais. O controle neural desse aparelho é exercido pelo sistema nervoso central (SNC), o qual é capaz de receber todas as informações que vêm da periferia (captadas pelos receptores específicos), processar essas informações e enviar uma resposta adequada por meio de contração muscular ou secreção glandular. 
Receptores localizados na pele e nas mucosas da cabeça são capazes de captar distintos tipos de estímulos (dor, tato discriminativo, pressão, temperatura etc.) e enviar essa informação ao SNC. Como vimos, nessa tarefa participam quatro pares de nervos cranianos: trigêmeo, facial, glossofaríngeo e vago. Os três últimos levam informação, fundamentalmente, de estruturas profundas como faringe, laringe, cavidade nasal, seios paranasais e orelha média. Em relação às estruturas externas, a participação desses três pares de nervos é muito modesta, limitando-se a inervar parte do pavilhão da orelha e do meato acústico externo. O restante da face e a cavidade bucal são inervados pelo n. trigêmeo.

O complexo nuclear trigeminal localiza-se no tronco encefálico. Estende-se desde a região rostral do mesencéfalo e alcança, em direção caudal, os primeiros segmentos da medula espinal. Desde o ponto de vista morfofuncional, pode ser dividido em quatro núcleos: mesencefálico, sensitivo principal, espinal e motor. Por sua vez, o núcleo espinal divide-se em sentido rostrocaudal em um subnúcleo oral, interpolar e caudal.

Estudos experimentais indicam que, dependendo do tipo de estímulo, distintos núcleos trigeminais são preferencialmente ativados. Assim, os estímulos dolorosos e térmicos provenientes da face e mucosa bucal parecem ser fundamentalmente processados pelo subnúcleo caudal do núcleo espinal; já os estímulos dolorosos provenientes da polpa dental parecem ser processados fundamentalmente pelos subnúcleos interpolar e caudal do núcleo espinal; estímulos de tato discriminativo (epicrítico) provenientes também da face e mucosa bucal acredita-se que sejam processados fundamentalmente pelo núcleo sensitivo principal e subnúcleos oral e interpolar do núcleo espinal. Os estímulos relacionados ao tato pouco discriminativo (protopático) parecem alcançar os diversos núcleos trigeminais. Finalmente, o núcleo mesencefálico processa estímulos proprioceptivos provenientes dos músculos da face.

A informação recebida e codificada pelos neurônios dos núcleos trigeminais é transmitida através de seus axônios a neurônios dos núcleos talâmicos específicos. A maior parte desses axônios de neurônios trigeminais cruza em direção contralateral e ascende pelo lemnisco trigeminal ventral com as fibras do lemnisco medial, que trazem informação sensitiva do resto do corpo, contatando sinapticamente com neurônios localizados no núcleo ventral posteromedial do tálamo. Alguns axônios, entretanto, ascendem ipsilateralmente, de forma que cada hemitálamo recebe e envia ao córtex cerebral informação sensorial proveniente de ambos os lados da face e da cavidade bucal.

Esses neurônios talâmicos (neurônio III na sequência hierárquica de processamento da informação sensorial; é preciso lembrar que o neurônio I estava localizado no gânglio trigeminal e o neurônio II nos núcleos trigeminais), por sua vez, fazem si- 
napse com neurônios localizados no córtex somestésico localizado no giro pós-central e na profundidade do sulco central. Os axônios dos neurônios talâmicos alcançam o córtex cerebral por meio da cápsula interna, um importante feixe de fibras onde se localiza a maior parte dos axônios que alcançam ou se originam no córtex cerebral.

Como tem sido demonstrado por uma série de estudos clínicos e experimentais, na área somestésica primária (SI) existe uma representação topográfica precisa, porém distorcida. A representação cortical destinada à face é desproporcionalmente grande, o que confirma a regra geral indicativa de importância funcional e não o tamanho de determinada região do corpo que determina sua representação no córtex cerebral.

Os neurônios corticais da região SI parecem processar, segundo estudos recentes, aspectos relacionados a textura, forma, consistência, localização periférica, direção de inclinação, início, terminação, amplitude, velocidade, duração e frequência de repetição e padrão temporal dos estímulos somestésicos, entretanto, para que se tome consciência do estímulo sensorial específico a informação recebida e processada em SI deve alcançar outras áreas corticais vizinhas (córtex associativo). Nessas áreas, o estímulo somestésico integra-se a estímulos relacionados com outras modalidades sensoriais que também levam, por vias independentes, informação relativa à informação sensorial específica. Esse conjunto de informações sensoriais, que "constroem" nossa imagem subjetiva, é enriquecido e valorizado pela comparação com situações precedentes que foram "armazenadas" na memória. Essa comparação pode permitir associar o estímulo a uma sensação de satisfação ou prazer. Assim, podemos agora valorizar e catalogar o estímulo inicial, atribuir-lhe um valor emocional preciso e responder de modo mais adequado.

\subsubsection{DINÂMICA BUCOFARÍNGEA}

Embora desde um ponto de vista didático seja apropriado dividir a inervação da boca a partir daquela fornecida pelos cinco pares de nervos citados, é evidente que o correto funcionamento do sistema estomatognático depende do funcionamento harmônico e cooperativo entre eles. A integração, muitas vezes reflexa, entre estímulos sensitivos e respostas motoras, incluindo as glandulares, ocorre em diversos níveis dentro do SNC.

Ao mastigar, por exemplo, os movimentos se iniciam com o abaixamento da mandíbula pela ação dos músculos pterigóideo lateral, milo-hióideo e ventre anterior do $\mathrm{m}$. digástrico, controlados pelo $\mathrm{V}$ par, mas também deve ocorrer a separação dos lábios, resultado do relaxamento do m. orbicular da boca, controlado pelo VII par, e relaxamento dos músculos elevadores da mandíbula (V par). A posterior elevação da mandíbula que leva à oclusão ocorre pela ação de 
músculos elevadores, como masseter, temporal e pterigóideo medial (V par). O bolo alimentar é mantido na área mastigatória pela ação da língua (XII par) e do m. bucinador (VII par). A localização precisa do bolo alimentar dentro da boca é captada pelos receptores somestésicos que recobrem a mucosa da língua, palato etc., todos relacionados com o V e IX pares. Esta ação mastigatória é repetida enquanto o bolo alimentar apresentar uma consistência imprópria para a deglutição. Essa consistência é captada pelos receptores localizados nos músculos, ligamento periodontal e ATM, todos também conectados ao V par craniano. Quando esta é adequada, o bolo é propelido em direção posterior e inicia-se a deglutição.

Quando alcança o terço posterior da língua, receptores somestésicos dessa região (IX par) desencadeiam uma série de movimentos reflexos nos músculos da língua (XII par), véu palatino e constritores da faringe (V, IX e X pares) que dificilmente podem ser inibidos, levando o bolo em direção ao esôfago. Ao mesmo tempo, a mandíbula é mantida em oclusão pela contração dos músculos elevadores (V par), permitindo assim que os músculos supra-hióideos (V, VII, IX) elevem o complexo osso hioide-laringe. A parte nasal da faringe é fechada pelos músculos do véu palatino (V, IX e X pares) e o óstio da tuba auditiva abre (X par). A abertura laríngea diminui como resultado da elevação do complexo osso hioide-laringe, e o esfíncter esofágico superior se abre (X par). Constantemente, informações somestésicas sobre a passagem do alimento são captadas pelos receptores relacionados com o V e IX pares e enviadas ao SNC de modo a coordenar a ação muscular.

Enquanto isso ocorre, receptores gustativos (VII e IX pares) informam ao $\mathrm{SNC}$ os aspectos relacionados ao sabor do alimento, o que interfere de forma consciente no ato de continuar ou não o processo mastigação/ingestão, e de forma inconsciente pela produção de saliva mediante as glândulas sublingual, submandibular (VII par), parótida (IX par) e glândulas salivares menores.

Assim, embora automático, o processo é muito complexo. Programas motores geridos e monitorados por áreas específicas do SNC permitem que a dinâmica mastigatória que envolve grupos musculares diversos controlados por distintos pares cranianos ocorra de modo reflexo. Essa complexidade passa a ser percebida, por exemplo, quando acidentes vasculares ou outras lesões do SNC alteram o funcionamento desses centros e exigem um demorado processo de reaprendizado. Claro que essa dinâmica neuromuscular não controla apenas as ações mastigatórias e da deglutição. Outras ações, como fala e sucção, dependem de dinâmicas e programas motores semelhantes que também são controlados por centros localizados no SNC e envolvem o funcionamento desses cinco pares de nervos cranianos. 


\section{REFERÊNCIAS BIBLIOGRÁFICAS}

BOILEAU GRANT, J. C.; BASMAJIAN, J. V. Grant's method of anatomy. 7 ed. Baltimore:Williams \& Wilkins, 1965.

CRUZ RIZZOLO, R. J.; MADEIRA, M. C. Anatomia facial com fundamentos de anatomia geral. 3 ed. (reimpressão), São Paulo: Sarvier, 2010.

JOHNSON, D. R.; MOORE, W. J. Anatomia para estudantes de odontologia. 3 ed. Rio de Janeiro: Guanabara Koogan, 1999.

MADEIRA, M. C. Anatomia da face. 7 ed. São Paulo: Sarvier, 2010.

MADEIRA, M. C.; CRUZ RIZZOLO, R. J. Anatomia do dente. 6 ed. São Paulo: Sarvier, 2010.

MARIEB, E. N.; HOEHN, K. Anatomia e fisiologia. 3 ed. Porto Alegre: Artmed, 2009.

MOORE, K. L. Anatomia orientada para a clínica. 3 ed. Rio de Janeiro: Guanabara Koogan, 1994.

SCOTT, J.H.; SYMONS, N. B. B. Introduction to dental anatomy. 4 ed. Edinburgh: E. \& S. Livingstone, 1964. 